\title{
Gummy Girl
}

\section{IsA IBAIBARRIAGA}

GP, Ediciones 2016

\author{
Mañana mentirás a tu propia juventud \\ A tu gran juventud luciérnaga \\ Los ecos solos harán moldes de todos los lugares que \\ existieron \\ $Y$ en la infinita vegetación transparente \\ Te pasearás con la celeridad \\ Que se pide a las bestias de los bosques \\ Acaso te desgranes entre mis despojos
}

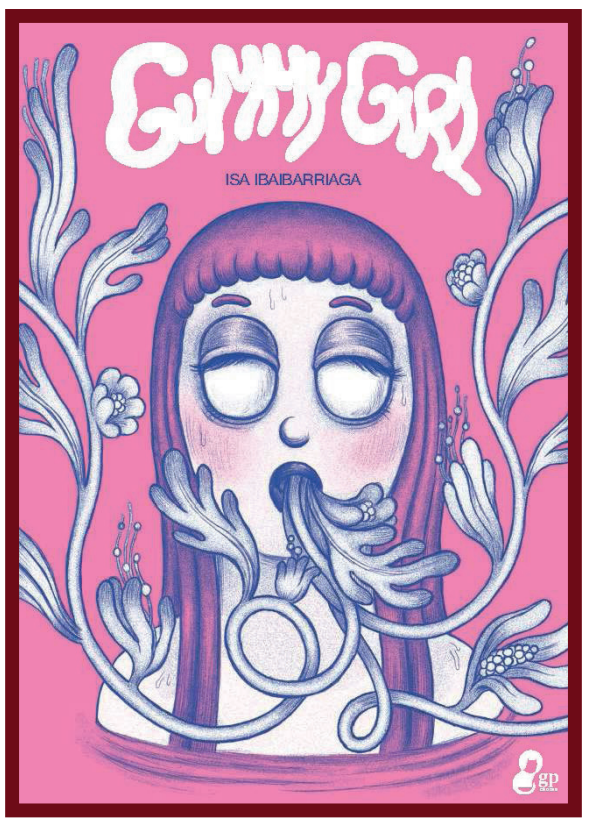

La Muerte Rosa, André Breton. ${ }^{1}$

T a piel desaparece. En el videoclip de Wide Open, los Chemical Brothers y Beck muestran a una mujer bailando al son de la música mientras su cuerpo se agujerea. Por decenas: las piernas, los brazos o la cara quedan transformados. Se teje una red. Los huecos sustituyen a la piel. La bailarina se agita. El efecto visual resulta agradable o repulsivo, en función de cómo se mire. Recuerda a esas imágenes que Google asimila a la palabra «dermatopatofobia» (o miedo a las enfermedades de la piel), muchas modificadas con Photoshop, algunas de enfermedades reales, en todos los casos reflejan deformidades en la dermis. Vacíos. Hileras de orificios que provocan aprensión pero que, al mismo tiempo, atraen por su continuidad. Todo por una razón: el miedo. Miedo a la transformación física. A la infección. A la enfermedad. O a la mutilación. El espectador siente una profunda empatía ante lo que ve. Se identifica y observa a su propio cuerpo modificado. Desmembrado y desagradable. Lo físico se torna en psicológico en lo que se conoce como «horror corporal». Una manifestación que gusta, que llena salas de cine, y que parte de la premisa de que lo mejor y lo peor procede del propio cuerpo humano y de sus obsesiones. Se suele relacionar con la idea estética de lo siniestro, que tan bien definió Freud, como algo ambivalente y por eso mismo terrible: el cuerpo es capaz de producirnos

${ }^{1}$ Breton, A. Clair de terre. Éditions Gallimard, 1966, pp. 106-108. Traducción libre. La poesía de Breton es rica en dobles sentidos que pueden apreciarse en la fuente original en francés. 


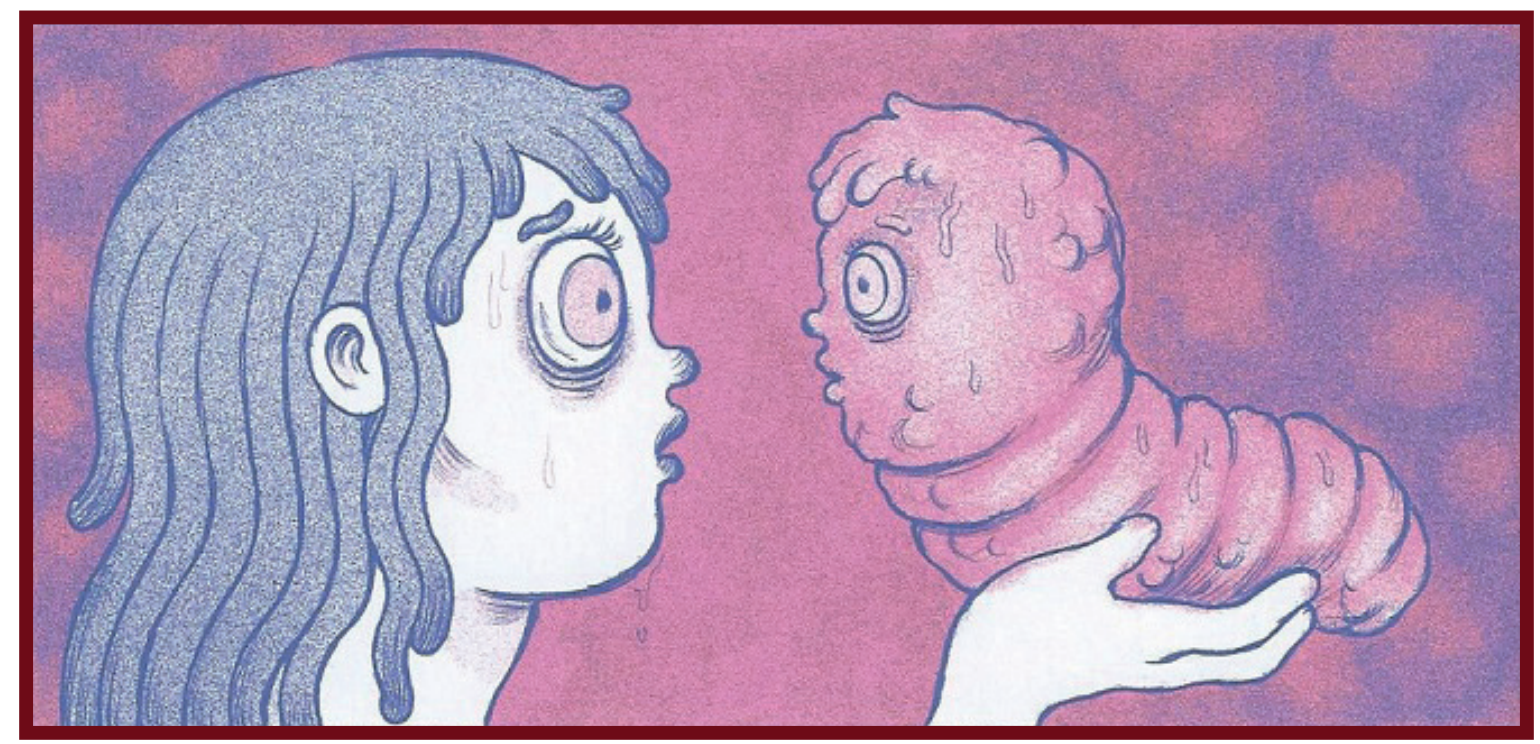

placer, pero también de hacer que experimentemos el dolor. Y en cómic tenemos una multitud de ejemplos de autores que explotan esta idea, muchos de ellos procedentes del manga: Suehiro Maruo, Junji Ito, Kazuo Umezu o Hideshi Hino. Influencias reconocidas para la creación de Gummy Girl.

Isa Ibaibarriaga (1990) es una joven aragonesa que ha conseguido despertar con su primer trabajo mucha atención de la crítica. Ha aparecido reseñada en los locales El Periódico de Aragón y Heraldo de Aragón, y en medios nacionales como las noticias de RTVE sobre cómic, con un artículo a cargo de Jesús Jiménez. También numerosos blogs sobre historieta se han hecho eco del lanzamiento del libro, donde la autora narra la vida de una estereotípica marginada al más puro estilo de high school norteamericana. Un relato como el de Holden Caulfield en El guardián entre el centeno de Salinger. De ansiedad y contradicciones adolescentes. Una bildungsroman o novela de iniciación, que retrata el paso de la niñez a la edad adulta. Pero en rosa. En ochenta páginas. Y en gore.

Se lee rápido y con avidez. Con ganas de llegar al final y con una narrativa que aprovecha perfectamente la tricromía entre blanco, negro y rosa palo. El color de los chicles de Boomer separa la realidad de un plano paralelo que podemos asociar a la ficción. Pero poco a poco el rosa va cobrando protagonismo hasta el desenlace, ayudado por un estilo de dibujo poco realista que se certifica ya en las ilustraciones que la autora había realizado para diversos proyectos anteriores. Destacan las ilustraciones que gozaron de un espacio en la librería $E l$ Armadillo Ilustrado de Zaragoza, para la exposición Cartoon soul.

Todos estos elementos nos llevan a una única conclusión: la perversión. Perversión de un relato literario iniciático contextualizado en un instituto de enseñanza. Perversión del color de Barbie, vinculado socialmente desde el siglo xIX a una concepción de lo femenino donde se daban cita la candidez y la ternura. Perversión que se ha atrevido a publicar la aragonesa GP Ediciones y detrás de la que se encuentra la Asociación Thermozero Cómics. Un breve 
relato de terror bien construido. Como un clip o una escena cinematográfica de un joven David Cronenberg. Como la danza de la actriz en Wide Open bajo las palabras de André Breton: Sonrie bailarina alrededor del único lustro que no caerá / Torno del tiempo / Subirélos corazones de los hombres / Para una suprema lapidación. Horror en rosa al servicio de los lectores.

\section{Julio Andrés Gracia Lana}

Está licenciado en Historia del Arte por la Universidad de Zaragoza, y especializado en arte contemporáneo por un máster de las Universidades Complutense y Autónoma de Madrid. Realiza el doctorado sobre edición de cómic en España gracias a una beca del Gobierno de Aragón y del Fondo Social Europeo, organiza eventos culturales, asiste a congresos y da clases (a veces, de cómic) en la Universidad de Zaragoza. Forma parte de la Asociación Aragonesa y de la Española de Críticos de Arte, y escribe en aacadigital.com. 